This article is licensed under the Creative Commons Attribution-NonCommercial 4.0 International License (CC BY-NC) (http://www.karger.com/Services/OpenAccessLicense).

\title{
Porta Hepatis Injury during Laparoscopic Cholecystectomy
}

\author{
Reem Shammout $^{\mathrm{a}} \quad$ Raiean Al Habbal $^{\mathrm{a}}$ Fadi Rayya $^{\mathrm{b}}$ \\ ${ }^{a}$ Faculty of Medicine, Damascus University, Damascus, Syria; bepartment of General \\ Surgery, Al-Assad University Hospital, Faculty of Medicine, Damascus University, \\ Damascus, Syria
}

\section{Keywords}

Conservative treatment · Laparoscopic cholecystectomy · Porta hepatis injury

\begin{abstract}
latrogenic porta hepatis injury is a rare but devastating surgical complication of laparoscopic cholecystectomy. There are no systematic studies examining the best treatment strategy in patients with this injury. We present a case of a 23-year-old woman with a large abscess in the right hepatic lobe due to an extreme vasculobiliary injury after laparoscopic cholecystectomy. Although rare, the impact of vasculobiliary injuries after cholecystectomy highlights the need for constant alertness and prompt management in order to minimize mortality and morbidity usually associated with the routine operative procedure.

(C) 2020 The Author(s)

Published by S. Karger AG, Basel
\end{abstract}

\section{Introduction}

Laparoscopic cholecystectomy is the procedure of choice for symptomatic cholecystolithiasis, and it is one of the most frequent operations in general surgery, which is considered as a safe operation. Unfortunately, it may be associated with an incidence of iatrogenic 


\section{Case Reports in Gastroenterology}

Case Rep Gastroenterol 2020;14:234-241

DOI: 10.1159/000507431

(c) 2020 The Author(s). Published by S. Karger AG, Basel www.karger.com/crg

Shammout et al.: Porta Hepatis Injury during Laparoscopic Cholecystectomy

extrahepatic bile duct and porta hepatis vessel injuries more than the open procedure $[1,2]$. Extreme vasculobiliary injuries which involve major hepatic arteries and portal veins are rare, but have severe consequences, including liver infarction, which is not uncommon, often with rapid onset and frequently necessitating emergency right hepatectomy or urgent liver transplantation [3], in addition to various degrees of hepatic ischemia with subsequent liver necrosis, abscess formation, acute liver failure or secondary biliary cirrhosis $[4,5]$. It is worth mentioning that among the structures involved in this type of injury, i.e., extrahepatic bile ducts, the hepatic arteries and portal vein, the latter is most likely to lead to a fatal outcome [6]. Portal vein and hepatic artery injuries are usually identified during surgery, because of the exsanguinating hemorrhage, unlike bile duct injuries, which may appear as occult injuries at time intervals distant from the injury [7].

\section{Case Presentation}

A 23-year-old female presented to our institution with abdominal pain, nausea, vomiting, fever, constipation, jaundice, and swelling of the abdomen. Considering her past medical history, the patient's symptoms had started after a complicated laparoscopic cholecystectomy 3 weeks ago, where during surgery, the patient suffered a massive bleeding due to porta hepatis injury, which led to the decision to change to open surgery (open cholecystectomy) and as a result the bleeding could be controlled. Physical examination revealed jaundice, palpitation, paroxysmal nocturnal dyspnea, mild cough with white sputum, polyarthralgia, bruising around the umbilicus, and there was no lymphadenopathy. The patient had an abdominal drainage, and about $200 \mathrm{~mL}$ of biliary secretion was coming out through it per day. Abdomen multislide computed tomography showed a cut injury in the right portal vein and right hepatic artery, with an abscess in the right hepatic lobe associated with necrotic areas in liver segments 5-6-7-8 (hepatic infraction), and there were clips in the right branch of porta hepatis (right portal vein and right hepatic artery) (Fig. 1,2). The patient was prepared for endoscopic retrograde cholangiopancreatography to locate the injury and possibly treat it. Endoscopic retrograde cholangiopancreatography showed that the duodenum and papilla were normal, the common bile duct was reflected, and it was interrupted at the level of the gallbladder clip. Intrahepatic bile ducts were not drawn. A sphincterotomy was performed, a catheter was inserted in the papilla, and the common bile duct was tied at the bifurcation. Despite the sphincterotomy, biliary secretions continued to come out through the abdominal drainage. So, based on clinical and radiological findings, we decided to do a laparotomy. Intraoperatively, we found a massive adhesion because of the last operation in addition to necrotic tissue and light local biliary peritonitis. Because of a fragile tissue, our very careful dissection in the porta hepatis in order to identify the right branches of the hepatic artery and the portal vein was unfortunately useless, so we removed the necrotic tissue and put drainage in the space. We decided to finish the procedure at this point to avoid any further injury and to reduce the postoperative morbidity. The patient did not need any intraoperative blood transfusion. Except for a biliary fistula, the postoperative period was uneventful. The patient was followed up for 7 months and she was in good general condition, and the biliary fistula stopped after 2 months. 


\section{Case Reports in Gastroenterology}

Case Rep Gastroenterol 2020;14:234-241

DOI: 10.1159/000507431

(c) 2020 The Author(s). Published by S. Karger AG, Base www.karger.com/crg

Shammout et al.: Porta Hepatis Injury during Laparoscopic Cholecystectomy

\section{Discussion}

Laparoscopic cholecystectomy is accepted as the gold standard in the surgical management of gallbladder disease. Despite the widespread application of this approach, the rate of common bile duct injury is still reported to be $0-2.7 \%$ for laparoscopic cholecystectomy. However, this percentage has decreased due to the increased experience in laparoscopic surgery [8]. Bile duct injuries are treated according to anatomical location and timing of detection, thus there is more than one protocol for repair. Intraoperative identification of a bile duct injury allows the possibility of immediate repair or appropriate nonoperative therapy. If an injury is suspected, intraoperative cholangiography can be beneficial in determining the extent of the problem and can help guide definitive repair [9]. Repair (laparoscopic or open) should be attempted only by surgeons with adequate training in hepatobiliary surgery. In postoperative presentation, subjectively, these patients often report abdominal pain or distension, nausea, fever and malaise. Objectively, they may show evidence of obstructive jaundice, sepsis, or documented bile leakage $[8,10,11]$. For patients with bile peritonitis, it is important to implement endoscopic retrograde cholangiopancreatography, or percutaneous transhepatic cholangiography, or cholangiography via magnetic resonance cholangiopancreatography. Likewise, control of biloma or bile peritonitis is imperative [9]. So, based on the patient's general stability, location of the injury, its scope and local experience, the surgeon must decide whether to proceed with immediate repair or to delay repair of the injury. Morbidity and mortality increase dramatically in vasculobiliary injuries, which means that bile duct and vascular injuries occur simultaneously. In these cases, successful outcome is unlikely when diagnosis of these is delayed. The extent of liver damage and the need for liver resection or transplant significantly influence the progress of patients with such injuries [12], and in other words, the prognosis depends on the severity of the injury. Vasculobiliary injuries may be classified into two types, of which one is common and the other is very uncommon. In the common variety, the right hepatic artery and a bile duct are injured. This variant accounts for about $90 \%$ of vasculobiliary injuries. The reason why the right hepatic artery is injured much more commonly than other arteries in association with a biliary injury is simply because it lies in closer proximity to the common hepatic duct. The uncommon type of vasculobiliary injury involves a bile duct(s) and the proper hepatic artery, the common hepatic artery, the main portal vein, the right portal vein, or one of these veins as well as a hepatic artery, possibly including the right hepatic artery. A recent review identified such patients in the literature $[13,15]$. Portal vein resistance to injury or underreporting of such cases due to rapid clinical deterioration and death may be some of the reasons [16]. There are some factors that increase the risk of injury. Excess or incorrect traction on the gallbladder while exposing the Calot's triangle can tent the common bile duct superiorly and expose it to injury. Misidentification of the correct anatomy, anatomic variations in bile duct anatomy or short cystic duct also predispose to ductal injury. Therefore, achieving a critical view of safety is useful for avoiding vasculobiliary injury during laparoscopic cholecystectomy [9]. We described the complications of an uncommon vasculobiliary injury in porta hepatis that was caused by laparoscopic cholecystectomy in another hospital; then the patient presented to our hospital, and her complications were managed successfully. Our case is one of the very rare cases in the literature, which was managed only with removing the necrotic tissue without hepatectomy or liver transplantation. We report this case because of its rareness and its importance in clinical 
practice, and to highlight the financial, social, and health disaster that may follow these injuries. We have attached Table 1 and Table 2 that summarize the cases that involved vasculobiliary injuries including the portal vein. We have added the result of our research to the reviewed cases in the above-mentioned studies [13,15], in addition to our case. Table 1 and Table 2 include the location of biliary, arterial and venous injury, the method of management, and the outcome whether the patient survived or died, with some other details.

Because of the reported rareness of these cases on the one hand and its devastating consequences on the other hand, it is important to compile the evidence and experience regarding porta hepatis injuries. Therefore, the present case contributes to the emerging literature about this issue. The most important result to be emphasized is that removing the necrotic hepatic tissue to manage the complications of this injury might be enough without the need for complex and dangerous procedures such as hepatectomy or liver transplantation. Finally, prevention is still the best way to avoid the risk of these injuries.

\section{Statement of Ethics}

In accordance with the Declaration of Helsinki, our study has been approved by the ethics committee of the Hospital. Informed consent to participate in our study has be obtained from the participant and her parents.

\section{Disclosure Statement}

The authors declare that there are no conflicts of interest regarding the publication of this paper.

\section{Funding Sources}

The authors received no funding or grant support.

\section{Author Contributions}

Fadi Rayya has performed the operation, organized the photos and reviewed the article. Reem Shammout and Raiean Al Habbal analyzed and interpreted the patient data and wrote the manuscript. All authors read and approved the final manuscript. 


\section{References}

1 Csikesz NG, Tseng JF, Shah SA. Trends in surgical management for acute cholecystitis. Surgery. 2008 Aug;144(2):283-9.

2 Manouras A, Pararas N, Antonakis P, Lagoudiannakis EE, Papageorgiou G, Dalianoudis IG, et al. Management of major bile duct injury after laparoscopic cholecystectomy: a case report. J Med Case Reports. 2009 Jan;3(1):44.

3 Strasberg SM, Gouma DJ. 'Extreme' vasculobiliary injuries: association with fundus-down cholecystectomy in severely inflamed gallbladders. HPB (Oxford). 2012 Jan;14(1):1-8.

4 Caminiti R, Rossitto M, Ciccolo A. Pseudoaneurysm of the hepatic artery and hemobilia: a rare complication of laparoscopic cholecystectomy; clinical case and literature review. Acta Chir Belg. 2011 NovDec;111(6):400-3.

5 Buell JF, Cronin DC, Funaki B, et al. Devastating and fatal complications associated with combined vascular and bile duct injuries during cholecystectomy. Arch Surg. 2002;137(6):703-8; discussion 708-10.

6 Busuttil RW, Kitahama A, Cerise E, McFadden M, Lo R, Longmire WP Jr. Management of blunt and penetrating injuries to the porta hepatis. Ann Surg. 1980 May;191(5):641-8.

7 Smith L. The Sir Ernest Finch memorial lecture 1978. Injuries of the liver, biliary trees, and pancreas. Br J Surg. 1978;0ct;65(10):673-7.

8 Csendes A, Navarrete C, Burdiles P, Yarmuch J. Treatment of common bile duct injuries during laparoscopic cholecystectomy: endoscopic and surgical management. World J Surg. 2001 Oct;25(10):1346-51.

9 Gupta V, Jayaraman S. Role for laparoscopy in the management of bile duct injuries. Can J Surg. 2017 Sep;60(5):300-4.

10 Strasberg SM, Hertl M, Soper NJ. An analysis of the problem of biliary injury during laparoscopic cholecystectomy. J Am Coll Surg. 1995 Jan;180(1):101-25.

11 Barband AR, Kakaei F, Daryani A, Fakhree MB. Relaparoscopy in minor bile leakage after laparoscopic cholecystectomy: an alternative approach? Surg Laparosc Endosc Percutan Tech. 2011 Aug;21(4):288-91.

12 Fonseca-Neto OC, Amorim AG, Lima JF, Melo CM. Emergency right hepatectomy for porta hepatis injury during laparoscopic cholecystectomy. Arq Bras Cir Dig. 2014 Jan-Mar;27(1):88-9.

13 Strasberg SM, Helton WS. An analytical review of vasculobiliary injury in laparoscopic and open cholecystectomy. HPB (Oxford). 2011 Jan;13(1):1-14.

14 Felekouras E, Megas T, Michail OP, Papaconstantinou I, Nikiteas N, Dimitroulis D, et al. Emergency liver resection for combined biliary and vascular injury following laparoscopic cholecystectomy: case report and review of the literature. South Med J. 2007 Mar;100(3):317-20.

15 Mathisen 0, Søreide 0, Bergan A. Laparoscopic cholecystectomy: bile duct and vascular injuries: management and outcome. Scand J Gastroenterol. 2002 Apr;37(4):476-81.

16 Jadrijevic S, Sef D, Kocman B, Mrzljak A, Matasic H, Skegro D. Right hepatectomy due to portal vein thrombosis in vasculobiliary injury following laparoscopic cholecystectomy: a case report. J Med Case Reports. 2014 Dec;8(1):412-412.

17 Frilling A, Li J, Weber F, Frühauf NR, Engel J, Beckebaum S, et al. Major bile duct injuries after laparoscopic cholecystectomy: a tertiary center experience. J Gastrointest Surg. 2004 Sep-Oct;8(6):679-85.

18 Madariaga JR, Dodson SF, Selby R, Todo S, Iwatsuki S, Starzl TE. Corrective treatment and anatomic considerations for laparoscopic cholecystectomy injuries. J Am Coll Surg. 1994 Sep;179(3):321-5.

19 Laurent A, Sauvanet A, Farges O, Watrin T, Rivkine E, Belghiti J. Major hepatectomy for the treatment of complex bile duct injury. Ann Surg. 2008 Jul;248(1):77-83.

20 Strasberg SM. Error traps and vasculo-biliary injury in laparoscopic and open cholecystectomy. J Hepatobiliary Pancreat Surg. 2008;15(3):284-92.

21 Ragozzino A, Lassandro F, De Ritis R, Imbriaco M. Value of MRI in three patients with major vascular injuries after laparoscopic cholecystectomy. Emerg Radiol. 2007 Nov;14(6):443-7.

22 Nishio H, Kamiya J, Nagino M, Uesaka K, Kanai M, Sano T, et al. Right hepatic lobectomy for bile duct injury associated with major vascular occlusion after laparoscopic cholecystectomy. J Hepatobiliary Pancreat Surg. 1999;6(4):427-30.

23 Robertson AJ, Rela M, Karani J, Steger AC, Benjamin IS, Heaton ND. Laparoscopic cholecystectomy injury: an unusual indication for liver transplantation. Transpl Int. 1998;11(6):449-51.

24 de Santibañes E, Palavecino M, Ardiles V, Pekolj J. Bile duct injuries: management of late complications. Surg Endosc. 2006 Nov;20(11):1648-53.

25 Thomson BN, Parks RW, Madhavan KK, Garden OJ. Liver resection and transplantation in the management of iatrogenic biliary injury. World J Surg. 2007 Dec;31(12):2363-9. 
Shammout et al.: Porta Hepatis Injury during Laparoscopic Cholecystectomy

26 Alves A, Farges O, Nicolet J, Watrin T, Sauvanet A, Belghiti J. Incidence and consequence of an hepatic artery injury in patients with postcholecystectomy bile duct strictures. Ann Surg. 2003 Jul;238(1):93-6.

27 Heinrich S, Seifert H, Krähenbühl L, Fellbaum C, Lorenz M. Right hemihepatectomy for bile duct injury following laparoscopic cholecystectomy. Surg Endosc. 2003 Sep;17(9):1494-5.

28 Zaydfudim V, Wright JK, Pinson CW. Liver transplantation for iatrogenic porta hepatis transection. Am Surg. 2009 Apr;75(4):313-6.

The datasets used during the current study are available from the corresponding author on reasonable request

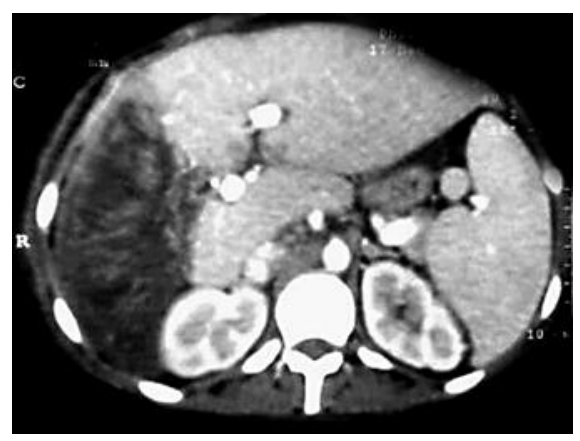

Fig. 1. Multislide computed tomography with intravenous contrast shows cut injury in the right hepatic artery and right portal vein.

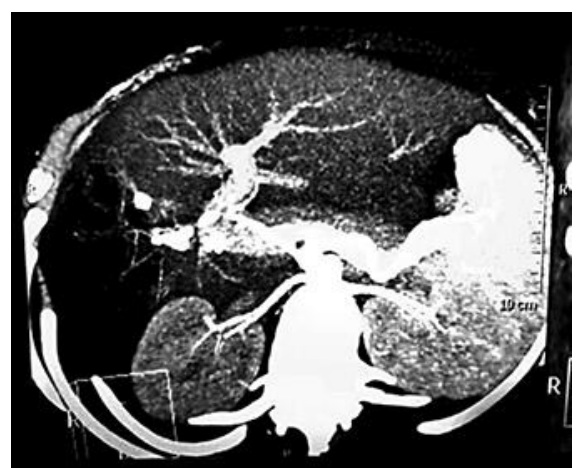

Fig. 2. Multislide computed tomography shows abscess in hepatic segments 5-6-7-8. 
Table 1. Vasculobiliary injuries involving the portal vein

\begin{tabular}{|c|c|c|c|c|c|c|c|}
\hline Authors & Portal vein injury & $\begin{array}{l}\text { Arterial in- } \mathrm{E} \\
\text { jury }\end{array}$ & $\begin{array}{l}\text { Biliary } \\
\text { injury }\end{array}$ & $\begin{array}{l}\text { Type of hepatic ische- } \\
\text { mia }\end{array}$ & $\begin{array}{l}\text { Type of liver } \\
\text { resection }\end{array}$ & $\begin{array}{l}\text { Timing of resection or } \\
\text { transplantation after } \\
\text { laparoscopic cholecys- } \\
\text { tectomy }\end{array}$ & Outcome \\
\hline $\begin{array}{l}\text { Felekouras } \\
\text { et al. [14] }\end{array}$ & Main portal vein & RHA & CBD & Rapid & R. hepatectomy & 1 day & $\begin{array}{l}\text { Died on day } 16 \\
\text { of sepsis }\end{array}$ \\
\hline $\begin{array}{l}\text { Frilling } \\
\text { et al. [17] }\end{array}$ & $\begin{array}{l}\text { Main portal vein and } \\
\text { superior mesenteric } \\
\text { vein }\end{array}$ & RHA & CHD & Rapid & R. hepatectomy & 16 days & $\begin{array}{l}\text { Died on day } 28 \\
\text { of sepsis and } \\
\text { multisystem or- } \\
\text { gan failure }\end{array}$ \\
\hline $\begin{array}{l}\text { Madariaga } \\
\text { et al. [18] }\end{array}$ & Main portal vein & RHA & CHD & Rapid & R. hemihepatectomy & 5 days & Survived \\
\hline $\begin{array}{l}\text { Madariaga } \\
\text { et al. [18] }\end{array}$ & $\begin{array}{l}\text { Right posterior portal } \\
\text { vein branch }\end{array}$ & RHA & CHD & Rapid & R. hemihepatectomy & 21 days & Survived \\
\hline $\begin{array}{l}\text { Laurent } \\
\text { et al. [19] (pt 2) }\end{array}$ & RPV & RHA & & Rapid & R. hepatectomy & 7 days & Survived \\
\hline Strasberg [20] & RPV & RHA & & Rapid & R. hepatectomy & 1 day & Survived \\
\hline $\begin{array}{l}\text { Ragozzino } \\
\text { et al. [21] (pt 1) }\end{array}$ & RPV & RHA & CBD & Rapid & R. hepatectomy & 1 day & Died day 15 \\
\hline $\begin{array}{l}\text { Ragozzino } \\
\text { et al. [21] (pt 2) }\end{array}$ & RPV & RHA & & Rapid & R. hepatectomy & 1 day & Survived \\
\hline $\begin{array}{l}\text { Nishio } \\
\text { et al. [22] }\end{array}$ & $\begin{array}{l}\text { Right anterior portal } \\
\text { vein }\end{array}$ & RHA & CBD & $\begin{array}{l}\text { Slow with abscess for- } \\
\text { mation }\end{array}$ & R. hepatectomy & 4 months & Survived \\
\hline $\begin{array}{l}\text { Robertson } \\
\text { et al. [23] }\end{array}$ & Left portal vein & PHA & & $\begin{array}{l}\text { Slow with abscess for- } \\
\text { mation }\end{array}$ & $\begin{array}{l}\text { Porto-enterostomy, or- } \\
\text { thotopic liver transplant }\end{array}$ & $\begin{array}{l}5 \text { months } \\
1 \text { year }\end{array}$ & Survived \\
\hline $\begin{array}{l}\text { de Santibañes } \\
\text { et al. [24] }\end{array}$ & $\begin{array}{l}\text { RPV (immediate re- } \\
\text { pair) }\end{array}$ & RHA & & Atrophy & $\begin{array}{l}\text { Orthotopic liver trans- } \\
\text { plant }\end{array}$ & 2 years & Survived \\
\hline $\begin{array}{l}\text { Laurent } \\
\text { et al. [19] (pt 7) }\end{array}$ & RPV & None & & None & R. hepatectomy & 8 years & Survived \\
\hline $\begin{array}{l}\text { Laurent } \\
\text { et al. [19] (pt 8) }\end{array}$ & RPV & None & & None & R. hepatectomy & 2.5 years & Survived \\
\hline $\begin{array}{l}\text { Thomson } \\
\text { et al. [25] (pt 3) }\end{array}$ & RPV & None & & Not stated & R. hepatectomy & Not stated & Survived \\
\hline $\begin{array}{l}\text { Thomson } \\
\text { et al. [25] (pt 12) }\end{array}$ & RPV & RHA & & Not stated & Awaiting liver transplant & & $\begin{array}{l}\text { Died at } 10.5 \\
\text { years }\end{array}$ \\
\hline $\begin{array}{l}\text { Thomson } \\
\text { et al. [25] (pt 13) }\end{array}$ & Left portal vein & $\begin{array}{l}\text { Common } \\
\text { hepatic ar- } \\
\text { tery }\end{array}$ & & Not stated & $\begin{array}{l}\text { Orthotopic liver trans- } \\
\text { plant }\end{array}$ & 4 months & Died \\
\hline $\begin{array}{l}\text { Alves } \\
\text { et al. [26] (3 pts) }\end{array}$ & Portal vein & RHA & & - & R. hemihepatectomy & 361 days & Survived \\
\hline $\begin{array}{l}\text { Alves } \\
\text { et al. [26] (1 pts) }\end{array}$ & Portal vein & None & & - & R. hemihepatectomy & 361 days & Survived \\
\hline $\begin{array}{l}\text { Heinrich } \\
\text { et al. [27] }\end{array}$ & RPV & RHA & RHD & - & R. hemihepatectomy & 2 weeks & Survived \\
\hline
\end{tabular}

All patients had an accompanying major biliary injury. CBD, common bile duct; CHD, common hepatic bile duct; LHA, left hepatic artery; MPV, main portal vein; PHA, proper hepatic artery; pt, patient; R, right; RHA, right hepatic artery; RHD, right hepatic duct; RPV, right portal vein. 


\section{Case Reports in Gastroenterology}

\begin{tabular}{l|l}
\hline Case Rep Gastroenterol 2020;14:234-241 \\
\hline DOI: 10.1159/000507431 & $\begin{array}{l}\text { ( ) 2020 The Author(s). Published by S. Karger AG, Basel } \\
\text { www.karger.com/crg }\end{array}$ \\
\hline
\end{tabular}

Shammout et al.: Porta Hepatis Injury during Laparoscopic Cholecystectomy

Table 2. Vasculobiliary injuries involving the portal vein (continued)

\begin{tabular}{|c|c|c|c|c|c|c|c|}
\hline Authors & Portal vein injury & $\begin{array}{l}\text { Arterial in- } \mathrm{E} \\
\text { jury }\end{array}$ & $\begin{array}{l}\text { Biliary } \\
\text { injury }\end{array}$ & $\begin{array}{l}\text { Type of hepatic ische- } \\
\text { mia }\end{array}$ & $\begin{array}{l}\text { Type of liver } \\
\text { resection }\end{array}$ & $\begin{array}{l}\text { Timing of resection or } \\
\text { transplantation after } \\
\text { laparoscopic cholecys- } \\
\text { tectomy }\end{array}$ & Outcome \\
\hline $\begin{array}{l}\text { Felekouras } \\
\text { et al. [14] }\end{array}$ & RPV & RHA & CBD & - & R. hepatectomy & $20 \mathrm{~h}$ & Died \\
\hline $\begin{array}{l}\text { Fonseca-Neto } \\
\text { et al. [12] }\end{array}$ & RPV & RHA & CHD & Rapid & R. hepatectomy & - & Survived \\
\hline $\begin{array}{l}\text { Zaydfudim } \\
\text { et al. [28] }\end{array}$ & $\begin{array}{l}\text { Transection of all } \\
\text { three portal struc- } \\
\text { tures }\end{array}$ & & & Rapid & Hepatectomy & $20 \mathrm{~h}$ & Survived \\
\hline \multirow[t]{7}{*}{$\begin{array}{l}\text { Strasberg } \\
\text { et al. [3] (7 pts) }\end{array}$} & RPV & RHA & $\begin{array}{l}\text { CBD transection } \\
\text { LHD laceration }\end{array}$ & & $\begin{array}{l}\text { Sutured portal vein. Pri- } \\
\text { mary repair of CBD and } \\
\text { LHD }\end{array}$ & & Survived \\
\hline & RPV & RHA & $\begin{array}{l}\text { CBD and CHD at } \\
\text { bifurcation }\end{array}$ & & $\begin{array}{l}\text { Hepaticojejunostomy af- } \\
\text { ter initial R. hepatectomy }\end{array}$ & 140 days & Survived \\
\hline & RPV & RHA & CHD & & $\begin{array}{l}\text { Right hepatectomy He- } \\
\text { patico-jejunostomy }\end{array}$ & 76 days & Died \\
\hline & RPV & RHA & $\begin{array}{l}\text { Necrosis of the } \\
\text { intrahepatic bili- } \\
\text { ary tree }\end{array}$ & & Liver transplant & 39 days & Died \\
\hline & RPV & RHA & Above confluence & & $\begin{array}{l}\text { Right colectomy with ile- } \\
\text { ostomy }\end{array}$ & & Survived \\
\hline & MPV & RHA & CHD & & $\begin{array}{l}\text { Emergency reconstruc- } \\
\text { tion of portal vein, PHA } \\
\text { and bile duct }\end{array}$ & $20 \mathrm{~h}$ & Died \\
\hline & MPV & PHA & Above confluence & & R. hepatectomy & 90 days & Died \\
\hline Jadrijevic et al. [16] & $\begin{array}{l}\text { Portal vein throm- } \\
\text { bosis and occlusion }\end{array}$ & RHA & CBD & & R. hepatectomy & 4 weeks & Survived \\
\hline Our case & RPV & RHA & $\begin{array}{l}\text { CBD at bifurca- } \\
\text { tion }\end{array}$ & $\begin{array}{l}\text { Slow with abscess for- } \\
\text { mation }\end{array}$ & $\begin{array}{l}\text { None (only removing the } \\
\text { abscess and the necrotic } \\
\text { tissue) }\end{array}$ & & Survived \\
\hline
\end{tabular}

All patients had an accompanying major biliary injury. CBD, common bile duct; CHD, common hepatic bile duct; LHA, left hepatic artery; MPV, main portal vein; PHA, proper hepatic artery; pt, patient; R, right; RHA, right hepatic artery; RHD, right hepatic duct; RPV, right portal vein. 